\title{
Comparative Study on Bacterial Outer Membrane Protein (BOMP) and Bacterial Outer Membrane Gene (BOMPG) Vaccination to Goldfish Carassius Auratus against Aeromonas Hydrophila
}

\author{
Sekar Divya, Vijayaragavan Thangaviji, Subramanian Velmurugan, Mariavincent Michaelbabu and Thavasimuthu Citarasu* \\ Centre for Marine Science and Technology, India \\ *Corresponding author: Thavasimuthu Citarasu, Centre for Marine Science and Technology, Manonmaniam Sundaranar University Rajakkamangalam, Kanyakumari, \\ 629502 Tamilnadu, India, Tel: 914652 253078; E-mail: citarasu@gmail.com, citarasu@msuniv.ac.in
}

Received date: 07 January 2015; Accepted date: 23 April 2015; Published date: 26 April 2015

Copyright: (c) 2015 Divya S, et al. This is an open-access article distributed under the terms of the Creative Commons Attribution License, which permits unrestricted use, distribution, and reproduction in any medium, provided the original author and source are credited.

Abstract
Aeromonas hydrophila is one of the serious bacterial pathogen in fresh water aquaculture industry. Recently,
some attention has been given to bacterial outer membrane protein (BOMP) as potentially important vaccine
components. Ornamental gold fish Carassius auratus immunized with the bacterial outer membrane protein
encoding gene clone, BOMPG-pTZ57R/T that was named as BOMPG and the bacterial outer membrane proteins
(BOMP) which were developed from a virulent strain of $A$. hydrophila and used as a vaccine candidate. In order to
study the comparative effects of the vaccines, BOMPG and BOMP were delivered to the experimental fishes (16.4 \pm
$1 \mathrm{~g}$ mean weight) by intra peritoneal injection once in every 15 days interval. At the end of the experiment, the
immunized and control fishes were challenged with virulent strain of $A$. hydrophila and assessed the immunological
parameters. $C$. auratus succumbed to death $100 \%$ at five days when no vaccination was given whereas the
vaccinated groups survived significantly (F=34.64; $P \leq 0.001)$ of 70 and $80 \%$ respectively in BOMPG and BOMP
after 10 days of challenge. Surprisingly the vaccinated groups help to decrease the Aeromonas sp. load in blood
and muscle of treated fishes and improve the serum biochemical parameters significantly $(P \leq 0.001)$ than the
control group. The haematological and immunological parameters were also improve significantly $(\mathrm{P} \leq 0.001)$ in the
BOMP vaccinated fishes due to the immune enhancement by the vaccines. Among the two different BOMP
deliveries, the BOMP highly influenced to improve the immune system against $A$. hydrophila challenge than
BOMPG. It may be the reason the BOMPG vaccine may easily degraded in vivo conditions.

Keywords: Aeromonas hydrophila; Carassius auratus; Outer membrane protein; Vaccine

\section{Background}

The ornamental fish trade in aquaculture sector has significant economic importance due to the high value of its exports. In 2007 alone, the value of export of ornamental fish across the world, as estimated by Food and Agriculture Organization of the United Nation (FAO), was reported to be 703 million dollars [1]. The art of rearing ornamental fish started around 800 B.C. in China with the gold fish Carassius auratus, which is in high demand and is still throughout the world even today [2]. Nowadays, ornamental fish aquaculture is facing lots of problems such as disease outbreaks, high mortality resulting in loss of economical output. Aeromonas hydrophila is an important fish pathogen in aquaculture systems and the diseases caused by this bacterium leading to severe damages and economic losses [3].

In this situation, the conventional treatment protocols against aquatic bacterial pathogens are rather difficult, non-effective, costly and causing environmental problems. Even though antibiotics and synthetic drugs give positive effects against pathogenic control, they cannot be advised due to their residual effects, resistant strain developments, bio-magnifications and suppression of immunity in host organisms [4]. Vaccination is the most efficacious and valuable tool in the prevention of infectious diseases, provided that they are administered prophylactically in anticipation of pathogen exposure.
Fish vaccination in the aquaculture industry has been considered to be very important in reducing economic losses caused by disease [5]

Recently BOMP is considered as highly immunogenic vaccine candidate and are located at host-bacterial interface and are important for host immune responses and as targets for drug therapy. BOMPs play a significant role in virulence as they comprise the outermost surface in contact with host cells and immune defence factors. Recombinant BOMPs have been tested as possible vaccine antigens for A. hydrophila. Fang et al. [3] showed significant protection against two isolates of $A$. hydrophila challenged in blue gourami, Trichogaster trichopterus immunised with a recombinant BOMP of $43 \mathrm{kDa}$. Recombinant BOMP ( $37 \mathrm{kDa}$ ) of $A$. hydrophila was also shown to be immunogenic in rohu carp [6].

Nucleic acid immunisation consists of inoculating a target animal with purified DNA or RNA containing a gene (s) under the control of an exogenous eukaryotic promoter, so that protective antigens are expressed within the host [7]. Nucleic acid vaccines potentially have a number of advantages over traditional attenuated, killed or subunit vaccines. They are cheaper and easier to produce than recombinant protein vaccines, have fewer adverse side effects and induce both cellular and humoral immune system [8]. The present study is to focus on the comparative effect of $A$. hydrophila BOMPG and BOMP used to immunize the ornamental gold fish, $C$. auratus against $A$. hydrophila challenge. 
Citation: Divya S, Thangaviji V, Velmurugan S, Michaelbabu M, Citarasu T (2015) Comparative Study on Bacterial Outer Membrane Protein (BOMP) and Bacterial Outer Membrane Gene (BOMPG) Vaccination to Goldfish Carassius Auratus against Aeromonas Hydrophila. J Vaccines Vaccin 6: 281. doi:10.4172/2157-7560.1000281

Page 2 of 7

\section{Materials and Methods}

\section{Source of BOMP clone (BOMPG)}

A. hydrophila BOMPG-pTZ57R/T recombinant plasmid [9] was transformed to E. coli DH5 competent cells used for immunization. The transformants were revived in LB broth in the presence of ampicillin and incubated at $37^{\circ} \mathrm{C}$ for $16 \mathrm{hrs}$. After $16 \mathrm{hrs}$, the cells were harvested by spun at $5,000 \mathrm{rpm}$ for $5 \mathrm{mins}$ and stored $4^{\circ} \mathrm{C}$. Lysate PCR amplification was also performed from the $E$. coli $\mathrm{DH} 5$ a cells using $A$. hydrophila specific OMP primer (Figure 1a).

\section{Source of Bacterial Outer Membrane Protein (BOMP)}

A highly virulent strain of $A$. hydrophila (AHV1; GenBank: HQ331525.1) was used in this study for extracting outer membrane protein. The BOMP was extracted by using the method of Chakraborty et al. [10] with some modifications. The A. hydrophila cell pellets were washed twice in Phosphate-Buffered Saline (PBS) and once in $10 \mathrm{mM}$ Tris-hydrochloride ( $\mathrm{pH}$ 7.5). Cells were re-suspended in $\mathrm{Tris}-\mathrm{HCl}$ and sonicated at $50 \mathrm{~W}$ for $30 \mathrm{~s}$ (4 times on ice). Following sonication, the suspension was mixed with Sarkosyl for solubilization of the OMP and incubated at $25^{\circ} \mathrm{C}$ for $30 \mathrm{~min}$. After incubation, the suspension was centrifuged at $4000 \times \mathrm{g}(20 \mathrm{~min})$, and the supernatant was collected. After centrifugation at $45000 \times \mathrm{g}(45 \mathrm{~min})$, the pellet was collected and stored at $20^{\circ} \mathrm{C}$ until it was used. The BOMP protein profile was analyzed by the method of Laemmli [11] using 10\% SDS PAGE and the BOMP was stored at $-20^{\circ} \mathrm{C}$ for further immunization study (Figure 1b).

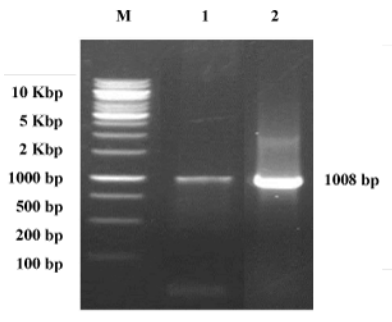

BOMPG (1a)

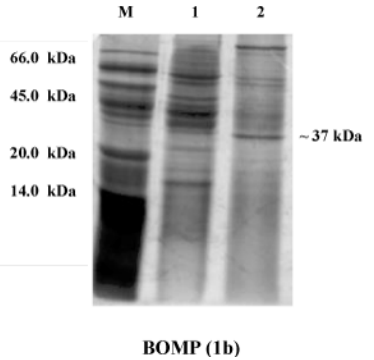

BOMP (1b)
Figure 1: A) A. hydrophila BOMPG clone in pTZ57R/T plasmid (BOMPG) Lanes: M-Marker; 1-PCR product of BOMPG; 2OMPG-pTZ57R/T clone. B) A. hydrophila Outer Membrane Protein (BOMP) extracted from virulent $A$. hydrophila. Lanes: MMarker; 1-A. hydrophila whole cell; 2-Bacterial Outer Membrane Protein (BOMP).

\section{Experimental set-up and vaccination}

The healthy $C$. auratus $(16.4 \pm 1 \mathrm{~g}$ mean weight) were purchased from local ornamental fish hatchery, transported to laboratory and acclimatized in 1000 l FRP tanks for 10 days. The fishes were fed ad libitum thrice daily with a formulated standard diet and commercial pellet feed at a ratio of $10 \%$ of their body weight throughout the period of study. Partial water exchange was performed daily to remove waste feed and faecal materials. Only healthy fish, as determined by general appearance and level of activity, were used for the experiment. After acclimatization, triplicate tanks containing a total of sixty fishes $(20 \times$ $3=60$ ) were maintained in each experimental and control groups. The tanks were of $500 \mathrm{l}$ capacity, flow-through aquaria with water flow rate of $1 \mathrm{ml} / \mathrm{min}$ and the fishes fed with commercial formulated feed of thrice a day in ad libitum. The vaccines including BOMPG clone and BOMP were administered to the experimental fishes by intraperitoneal injection at 1 and 15th days. The vaccine delivery dose for BOMPG was $10^{7} \mathrm{cfu} / \mathrm{ml}$ bacterial cells and $200 \mu \mathrm{g}$ total protein of BOMP per fishes in each injection. The blank control (BC) group received no vaccine delivery and no $A$. hydrophila challenge. The control (C) group received the $E$. coli cells at the density of $10^{7} \mathrm{cfu} / \mathrm{ml}$ without BOMPGpTZ57R/T clone and A. hydrophila challenge.

\section{Challenge with virulent Aeromonas hydrophila}

After the termination of culture period, virulent $A$. hydrophila were injected to the experimental and control (C) fishes by intraperitoneally at the rate of $10^{7} \mathrm{cfu} / \mathrm{ml}$. The cumulative mortality was monitored for a group of fishes in all experiments and the rest were sacrificed and bled the blood for biochemical, haematological and immunological parameters.

\section{Cumulative mortality and Specific bacterial count}

The cumulative mortality in A. hydrophila was assessed after challenge for 10 days. The randomly selected fishes from each group were weighed aseptically and immersed in $50 \mathrm{ppm}$ formalin solution for $5 \mathrm{~min}$ (to remove external bacteria present on the goldfish). They were rinsed thoroughly with sterilized water for $30 \mathrm{sec}$ to remove the remaining surface bacteria and disinfectant. The washed muscle were homogenized with $5 \mathrm{ml}$ of sterile distilled water and serially diluted up to 10 -fold. Sample of $0.5 \mathrm{ml}$ was taken with the help of sterilized pipette and poured into Aeromonas isolation agar medium-M884 (HIMEDIA, India). Triplicate plate count were maintained in each sample and incubated at $37^{\circ} \mathrm{C}$ for $48 \mathrm{~h}$.

\section{Biochemical parameters}

Saturated ammonium sulphate was added to $100 \mu \mathrm{l}$ of serum in micro centrifuge tube, mixed well and left to stand for 1 hour at room temperature. The tubes were then centrifuged at $10,000 \mathrm{rpm}$ for 10 minutes and the supernatant (albumin fraction) was collected into separate tubes. The precipitate (globulin fraction) was dissolved in 500 $\mu \mathrm{l}$ of distilled water. The protein content of both albumin and globulin fractions were determined [12]. Total serum protein was determined at $650 \mathrm{~nm}$ under UV visible spectrophotometer by using bovine serum albumin (BSA) as standard protein.

\section{Haematological parameters}

Haemoglobin level was determined by haemoglobin cyanide method described by Van Kampen and Zijlstra [13]. Total erythrocyte count was performed following the method of Hendricks [14] using a haemocynometer.

\section{Immunological parameters}

The Haemagglutination assay of serum samples was carried out using the method described by Sritunyalucksana et al. [15]. This assay was performed in $U$ shaped micro well plates. Two fold dilution of serum samples were made in $1 \times$ tris buffered saline (TBS). An equal volume of $1.5 \%$ RBC was added to each dilution of serum sample. The plates were incubated at $37^{\circ} \mathrm{C}$ for $30 \mathrm{~min}$. Haemagglutination titre was recorded as the reciprocal of last dilution, resulting in agglutination 
Citation: Divya S, Thangaviji V, Velmurugan S, Michaelbabu M, Citarasu T (2015) Comparative Study on Bacterial Outer Membrane Protein (BOMP) and Bacterial Outer Membrane Gene (BOMPG) Vaccination to Goldfish Carassius Auratus against Aeromonas Hydrophila. J Vaccines Vaccin 6: 281. doi:10.4172/2157-7560.1000281

Page 3 of 7

after 30 minutes incubation. Negative controls comprised of equal volume of RBC and TBS. Phagocytosis was performed following the method of Park and Jeong [16] using formalin killed A. hydrophila at the rate of $10^{7} \mathrm{cfu} / \mathrm{ml}$ with $0.1 \mathrm{ml}$ of blood samples of each groups. Bactericidal activity was determined in vivo i.e., fish were injected with $10^{7} \mathrm{cfu}$ of live $A$. hydrophila suspension and the blood samples were collected from the fishes after 10 and 90 min intervals. One hundred micro liters of blood was serially diluted and spread plated in triplicate on TSB agar plates (HIMEDIA, India) and incubated at $34^{\circ} \mathrm{C}$ for $24 \mathrm{~h}$. From the total number of $A$. hydrophila colonies in each plate, total colony forming unit (cfu) in each blood sample was estimated. Intraagar lysozyme activity was performed against Micrococcus luteus culture by diluting the blood cells and inoculating a drop upon the agar wells. The drops were allowed to absorb onto the agar and were incubated in a inverted manner for $24-48 \mathrm{hrs}$ at $37^{\circ} \mathrm{C}$. The plates for the highest dilution of blood cells capable of lysing the test microbes were then scored.

\section{Data analysis}

One way and two way analysis of variance (ANOVA) were carried out using SPSS statistics data package and Ky plot respectively. Positive correlation analysis also performed to compare the data by Microsoft Excel programme. Means were compared at 0.05, 0.01 and $0.001 \%$ level.

\section{Results}

\section{Cumulative mortality of $\boldsymbol{C}$. auratus after challenge}

C. auratus succumbed to $100 \%$ death within five days after being challenged with virulent $A$. hydrophila. The BOMP vaccines helped to increase the survival to 70 and $80 \%$ respectively in BOMPG and BOMP treated groups. Only $10 \%$ of cumulative mortality was varied among the vaccine treated fishes and the two way ANOVA revealed that the values significantly differed from each other's (Column: $\mathrm{F}=50.62 ; \mathrm{P} \leq 0.001$ and Row: $\mathrm{F}=2.38 ; \mathrm{P} \leq 0.05$ ) (Figure 2).

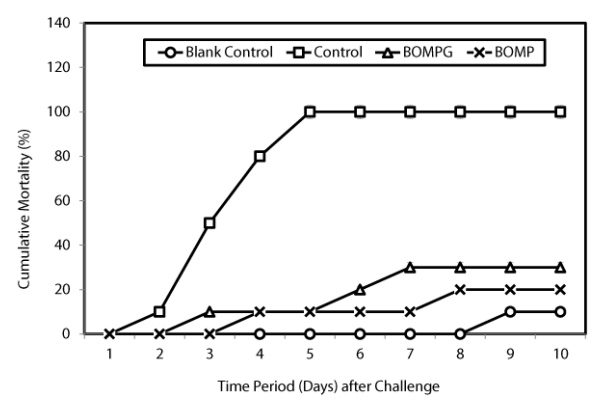

Figure 2: Cumulative mortality (\%) of BOMP vaccines treated goldfish $C$. auratus against virulent $A$. hydrophila challenge after termination of experiment. The values are significantly differed each other's (Column: $\mathrm{F}=50.62 ; \mathrm{P} \leq 0.001$ and Row: $\mathrm{F}=2.38 ; \mathrm{P} \leq$ 0.05)-two way ANOVA

\section{Specific bacterial count in blood and muscle}

The specific Aeromonas count of the control and vaccinated fishes are given in the Table 1 . The bacterial loads observed of $1.5 \times 10^{6}$ $\mathrm{cfu} / \mathrm{ml}$ and $7.4 \times 10^{5} \mathrm{cfu} / \mathrm{g}$ after 8 days from challenge in blood and muscle respectively. After 2 days from the challenge, the load was observed to be $1.8 \times 10^{4}$ and $1.6 \times 10^{4} \mathrm{cfu} / \mathrm{ml}$ in the blood of BOMPG and BOMP treated C. auratus respectively. Surprisingly, the BOMP vaccines decreased the load to $1.1 \times 10^{2}$ and $3.5 \times 10 \mathrm{cfu} / \mathrm{ml}$ respectively in the blood of BOMPG and BOMP treated $C$. auratus. The same trend of reduction was also observed in the muscle.

\begin{tabular}{|c|c|c|c|c|c|c|}
\hline & \multicolumn{6}{|c|}{ Aeromonas Count } \\
\hline & \multicolumn{3}{|c|}{ Blood (cfu ml-1) } & \multicolumn{3}{|c|}{ Muscle (cfu g-1) } \\
\hline & 2 Days & 4 Days & 8 Days & 2 Days & 4 Days & 8 Days \\
\hline $\begin{array}{l}\text { Blank } \\
\text { Control }\end{array}$ & - & $\begin{array}{l}0.3 \times 10^{1} \\
\pm \\
0.1 \times 10^{1}\end{array}$ & $\begin{array}{l}0.5 \times 10^{1} \\
\pm \\
0.1 \times 10^{1}\end{array}$ & - & - & $\begin{array}{l}0.2 \times 10^{1} \\
\pm \\
0.01 \times 10^{1}\end{array}$ \\
\hline Control & $\begin{array}{l}4.4 \times 10^{4} \\
\pm \\
0.21 \times 10^{1}\end{array}$ & $\begin{array}{l}8.6 \times 10^{5} \\
\pm \\
0.5 \times 10^{1}\end{array}$ & $\begin{array}{l}1.5 \times 10^{6} \\
\pm \\
1.4 \times 10^{1}\end{array}$ & $\begin{array}{l}3.6 \times 10^{2} \\
0.3 \times 10^{1}\end{array}$ & $\begin{array}{l}1.4 \times 10^{3} \pm \\
0.15 \times 10^{1}\end{array}$ & $\begin{array}{l}7.4 \times 10^{5} \\
\pm \\
0.11 \times 10^{1}\end{array}$ \\
\hline $\begin{array}{l}\text { BOMP } \\
\text { G }\end{array}$ & $\begin{array}{l}1.8 \times 10^{4} \\
\pm \\
0.10 \times 10^{1}\end{array}$ & $\begin{array}{l}4.0 \times 10^{3} \\
\pm \\
0.05 \times 10^{1}\end{array}$ & $\begin{array}{l}1.1 \times 10^{2} \\
\pm \\
0.3 \times 10^{1}\end{array}$ & $\begin{array}{l}6.3 \times 10^{3} \pm \\
0.2 \times 10^{1}\end{array}$ & $\begin{array}{l}1.2 \times 10^{3} \pm \\
0.3 \times 10^{1}\end{array}$ & $\begin{array}{l}8.5 \times 10^{2} \\
\pm \\
0.10 \times 10^{1}\end{array}$ \\
\hline BOMP & $\begin{array}{l}1.6 \times 10^{4} \\
\pm \\
0.06 \times 10^{1}\end{array}$ & $\begin{array}{l}1.1 \times 10^{2} \\
\pm \\
0.02 \times 10^{1}\end{array}$ & $\begin{array}{l}3.5 \times 10^{1} \\
\pm \\
0.05 \times 10^{1}\end{array}$ & $\begin{array}{l}19.5 \times 10^{2} \\
\pm \\
0.05 \times 10^{1}\end{array}$ & $\begin{array}{l}8.7 \times 10^{2} \pm \\
0.04 \times 10^{1}\end{array}$ & $\begin{array}{l}1.2 \times 10^{2} \\
\pm \\
0.01 \times 10^{1}\end{array}$ \\
\hline
\end{tabular}

Table 1: Aeromonas count from blood and muscle samples from BOMP vaccinated $C$. auratus after A. hydrophila challenge at different time intervals.

\section{Biochemical parameters of $C$. auratus after challenge}

Serum albumin in the blood was found to be $241.25 \mu \mathrm{g} / \mathrm{ml}$ in $C$. auratus when no vaccination was given. The level was increased significantly ( $\mathrm{P} \leq 0.001)$ to 252.45 and $268.22 \mu \mathrm{g} / \mathrm{ml}$ in BOMPG and BOMP treated groups. The globulin level also increased in the same way as albumin in the vaccinated groups with a maximum of 245.2 $\mu \mathrm{g} / \mathrm{ml}$ in BOMP treated fishes. Serum protein in the blood was 466.30 $\mu \mathrm{g} / \mathrm{ml}$ in $C$. auratus with no vaccination and it increased significantly $(\mathrm{P} \leq 0.001)$ to 485.34 and $518.04 \mu \mathrm{g} \mathrm{cfu} / \mathrm{ml}$ respectively in the BOMPG and BOMP treated groups (Figure 3 ). The two vaccinated groups of BOMPG and BOMP were influenced to increase the biochemical parameters such as serum albumin, serum globulin and serum protein. The BOMP vaccines helped to increase the serum biochemical parameters around $4 \%$ than the BOMPG group by the effective antigen presentation and higher antibody production. The positive correlation analysis also revealed a significant relationship $(\mathrm{P}<0.05)$ found among the treatment from control to experimental groups (Figures $4 \mathrm{a}-4 \mathrm{c}$ ). 
Citation: Divya S, Thangaviji V, Velmurugan S, Michaelbabu M, Citarasu T (2015) Comparative Study on Bacterial Outer Membrane Protein (BOMP) and Bacterial Outer Membrane Gene (BOMPG) Vaccination to Goldfish Carassius Auratus against Aeromonas Hydrophila. J Vaccines Vaccin 6: 281. doi:10.4172/2157-7560.1000281

Page 4 of 7

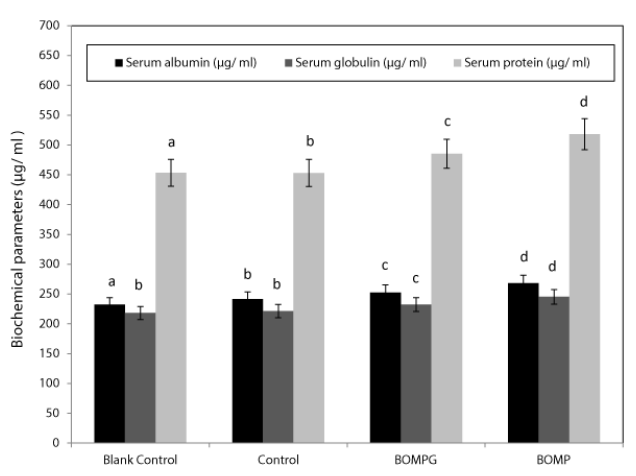

Figure 3: Biochemical changes of BOMP vaccinated C. auratus after A. hydrophila challenge Means with the same superscripts (a-d) do not differ from each other-One Way ANOVA $(\mathrm{P} \leq 0.001)$.

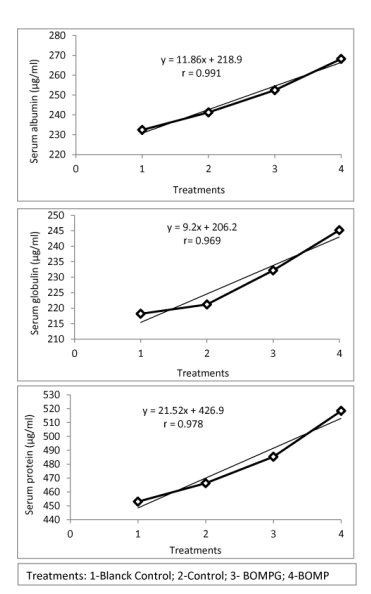

Figure 4: Positive correlation between control and vaccine treated fishes' serum biochemical parameters. Values are the mean of three determinations \pm SEM $(\mathrm{P}<0.05)$.

\section{Haematological parameters of $C$. auratus after challenge}

The red blood cell (RBC) count was recorded of $46.2 \times 10^{2} / \mathrm{mm}^{3}$ in blank control fish group, whereas the count was drastically decreased to $29.28 \times 10^{2} / \mathrm{mm}^{3}$ in control group by $A$. hydrophila interruption. Surprisingly the $\mathrm{RBC}$ count was significantly $(\mathrm{P} \leq 0.01)$ increased to 48.4 and $52.3 \times 10^{2} / \mathrm{mm}^{3}$ in BOMPG and BOMP respectively. The haemoglobin level was observed to be $4.39 \mathrm{mg} / \mathrm{dl}$ in $C$. auratus challenged with $A$. hydrophila without vaccine treatment. The vaccine BOMP helped to increase the haemoglobin level significantly ( $\mathrm{P} \leq$ 0.001 ) of $9.83 \mathrm{mg} / \mathrm{dl}$ (Figure 5).

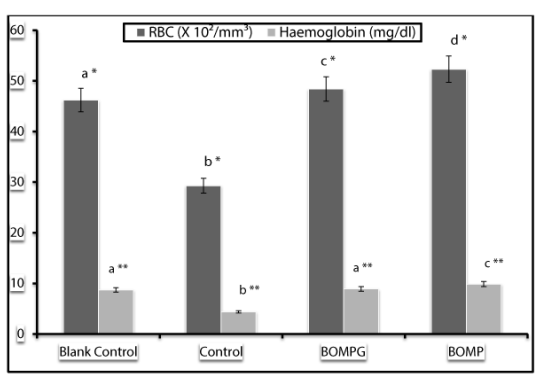

Figure 5: Haematological parameters such as RBC and haemoglobin of BOMP vaccines treated goldfish $C$. auratus against virulent $A$. hydrophila challenge after 30 days. Means with the same superscripts (a-d) do not differ from each other - one way ANOVA ${ }^{\star}(\mathrm{P} \leq 0.01) ;{ }^{* *}(\mathrm{P} \leq 0.001)$.

\section{Immunological parameters of $\boldsymbol{C}$. auratus after challenge}

Haemagglutination assay were carried out against the RBC of human A, B and O blood groups (Table 2). The vaccine treated C. autatus antigen reacted against the human $\mathrm{RBC}$ even at 1:4 and 1: 16 dilutions in the BOMPG and BOMP respectively. The BOMP helps to improve the immune efficiency at one time in $C$. auratus against $A$. hydrophila. Phagocytic activity was observed to be $18.23 \%$ in control group (Figure 6), and this was increased significantly $(\mathrm{P} \leq 0.001)$ to 49.73 and $55.11 \%$ in BOMPG and BOMP treated fishes against $A$. hydrophila challenge. The serum bactericidal activity also showed the same trend about $4.15 \%$ in the control fishes whereas this was significantly ( $\mathrm{P} \leq 0.001)$ increased to 14.33 and $17.07 \%$ in BOMPG and $\mathrm{BOMP}$ treated fishes respectively. The activity was increased more than three times than the control fishes against BOMP treated fishes (Figure 6). The intra-agar lysozyme assay against Micrococcus luteus revealed that less activity of $4.93 \mathrm{~mm}$ zone of inhibition was found in the serum of control fishes. The serum from vaccinated fishes helped to increase the activity to 14.83 and $17.72 \mathrm{~mm}$ of zone of inhibition against $M$. luteus in BOMPG and BOMP treated fishes respectively. One way ANOVA revealed that, the activity significantly differed from each other's ( $\mathrm{P} \leq 0.001$-Table 3$)$.

\section{Discussion and Conclusion}

Considerable interest has been shown in bacterial OMP vaccines since these were thought to contain some of the major antigens responsible for inducing an immune response in the host $[3,17]$. The outer membrane proteins of $A$. hydrophila have a role in the virulence of the organism and are potential candidates for vaccine development [18]. The present study, outer membrane proteins play a significant role in virulence as they comprise the outermost surface in contact with host cells and immune defense factors. Earlier works supported $C$. auratus vaccinated with recombinant OMP showed a higher percentage of survival after a virulent $A$. hydrophila challenge [9]. $C$. auratus vaccinated with $A$. hydrophila BOMP revealed that, the vaccinated fishes survived more than $70 \%$ after challenge. Among the two treatments such as BOMPG and BOMP in $C$. auratus, the BOMP vaccine was highly influenced to improve the survival, biochemical, haematological and immunological parameters. 
Citation: Divya S, Thangaviji V, Velmurugan S, Michaelbabu M, Citarasu T (2015) Comparative Study on Bacterial Outer Membrane Protein (BOMP) and Bacterial Outer Membrane Gene (BOMPG) Vaccination to Goldfish Carassius Auratus against Aeromonas Hydrophila. J Vaccines Vaccin 6: 281. doi:10.4172/2157-7560.1000281

Page 5 of 7

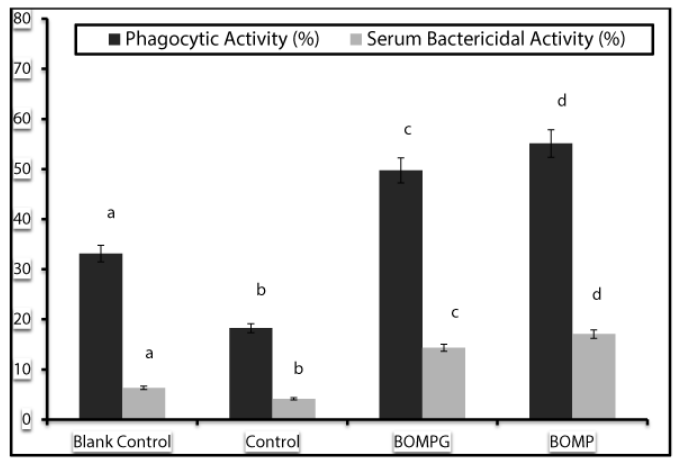

Figure 6: Phagocytic activity and serum bactericidal activity (\%) of BOMP vaccines treated goldfish $C$. auratus against the virulent $A$. hydrophila challenge after 30 days. Means with the same superscripts (a-d) do not differ from each other-one way ANOVA $(\mathrm{P} \leq 0.001)$.

The BOMP was helped to reduce the specific bacterial load at a higher level than the BOMPG after A. hydrophila challenge. The higher level reduction was found in muscle and blood of BOMP treatment than the BOMPG delivered $C$. auratus after $A$. hydrophila challenge. The BOMP vaccine helped to increase the production of higher antibody production against $A$. hydrophila outer membrane protein. This higher antibody production level may be suppressed the growth of $A$. hydrophila load. The earlier report by Thangaviji et al. $[19,20]$ showed that the $A$. hydrophila OMP and biofilm vaccines with the herbal immunoadjuvant, Asparagus racemosus extracts helped to decrease the Aeromonas load of $1.1 \times 102$ and $0.5 \times 102 \mathrm{cfu} / \mathrm{g}$ respectively in the muscles on the 50th day of vaccination.

Generally there is an increased serum biochemical parameters observed in immunized fishes with vaccines or immunostimulants. Vaccination of $A$. hydrophila ECP, OMP and biofilm with herbal immuno-adjuvant helped to increase the serum albumin and globulin levels in C. auratus [20]. The herbal immunostimulants obtained from plants such as Lonicera japonica and Ganoderma lucidum helped to increase the immunoglobulin level in Oreochromis niloticus against $A$. hydrophila challenge [21]. Dina Rairakhwada et al. [22] also found that the globulin level was significantly increased in the levan; an immunostimulant fed common carp fingerlings after challenged with A. hydrophila. Misra et al. [23] also reported that total serum protein content increased significantly in the fish fed with dietary doses of $\beta$ glucan when compared with control group. Since serum proteins include various humoral elements of the non-specific immune system, high concentrations of total serum protein, albumin and globulin might be due to the enhancement of non-specific immune response of fishes.

\begin{tabular}{|l|l|l|l|l|}
\hline \multirow{2}{*}{ Treatments } & Dilutions & \multicolumn{3}{|l|}{ Blood Group } \\
\cline { 3 - 5 } & & A & B & O \\
\hline \multirow{2}{*}{ Blank Control } & Negative control & + & + & + \\
\cline { 2 - 5 } & Positive control & - & - & - \\
\cline { 2 - 5 } & $1: 1$ & - & - & - \\
\hline Control & Negative control & + & + & + \\
\hline
\end{tabular}

\begin{tabular}{|l|l|l|l|l|}
\hline \multirow{5}{*}{ BOMPG } & Positive control & - & - & - \\
\cline { 2 - 5 } & $1: 1$ & - & - & - \\
\hline & $1: 1$ & + & + & + \\
\cline { 2 - 5 } & $1: 2$ & + & + & + \\
\hline & $1: 4$ & - & + & + \\
\hline & $1: 8$ & - & - & + \\
\hline \multirow{5}{*}{ BOMP } & $1: 16$ & - & - & - \\
\hline $1: 1$ & $1: 2$ & + & + & + \\
\hline & $1: 4$ & + & + & + \\
\hline & $1: 8$ & + & + & + \\
\hline & $1: 16$ & + & + & + \\
\hline & $1: 32$ & - & + & + \\
\hline & $1: 3$ & - & - \\
\hline
\end{tabular}

Table 2: In vitro haemoagglutinin assay of BOMP vaccine treated $C$. autratus's blood with human $\mathrm{A}, \mathrm{B}$ and $\mathrm{O}$ and groups $\mathrm{RBC}$ after $30^{\text {th }}$ day immunization after challenged with $A$. hydrophila.

\begin{tabular}{|c|c|c|c|c|}
\hline \multirow[t]{3}{*}{ Treatments } & \multicolumn{4}{|c|}{ Lysozyme activity $(\mathrm{mm})$} \\
\hline & \multicolumn{4}{|l|}{ Dilution factor } \\
\hline & Blank (DH2O) & $10-{ }^{3}$ & $10^{-4}$ & $10^{-5}$ \\
\hline Control (C) & $0.0 \pm 0.0$ & $\begin{array}{l}4.93^{\mathrm{a}} \\
\pm \\
0.04\end{array}$ & $\begin{array}{l}4.06^{a} \\
\pm \\
0.10\end{array}$ & $\begin{array}{l}2.40^{\mathrm{a}} \\
\pm \\
0.03\end{array}$ \\
\hline BOMPG & $0.0 \pm 0.0$ & $\begin{array}{l}14.83^{b} \\
0.04\end{array}$ & $12.84^{b} \pm 0.03$ & $9.84^{b} \pm 0.02$ \\
\hline BOMP & $0.0 \pm 0.0$ & $\begin{array}{l}17.72^{\mathrm{c}} \quad \pm \\
0.05\end{array}$ & $14.06^{c} \pm 0.01$ & $11.77^{c} \pm 0.02$ \\
\hline
\end{tabular}

Table 3: Zone formations ( $\mathrm{mm}$ ) of intra-agar lysozyme activity of the blood of $C$. auratus treated with BOMP vaccine and challenged with $A$. hydrophila after 30 days immunization. Means with the same superscripts (a-c) do not differ from each other- One Way ANOVA, (P $\leq 0.001)$

Blood cells play an important role in cellular defence mechanisms. The decreased number of circulating cells in the host blood indicates that, the system is less resistance against pathogens. In the present study, RBC and haemoglobin level was found to be a maximum of 52.3 $\times 10^{2} / \mathrm{mm}^{3}$ and $9.86 \mathrm{mg} / \mathrm{dl}$ in the fishes immunized with BOMP. The BOMP vaccine helped to increase the $\mathrm{RBC}$ level to $78 \%$ and haemoglobin level to $124 \%$ from the control groups due to higher immune response in the vaccinated fishes. The low level of RBC found in the control fishes suffered to loss of body fluids, oxygen carrying capacity and finally leading to mortality. The decreased RBC, haematocrit, and haemoglobin levels in the infected and untreated fishes indicated that, the blood cells destroyed by leukocytosis with subsequent erythroblastosis [24]. Sahu et al. [25] reported that WBC and RBC counts were higher in Labeo rohita fingerlings fed $M$. indica kernel when compared to the control. In rainbow trout, Oncorhynchus 
Citation: Divya S, Thangaviji V, Velmurugan S, Michaelbabu M, Citarasu T (2015) Comparative Study on Bacterial Outer Membrane Protein (BOMP) and Bacterial Outer Membrane Gene (BOMPG) Vaccination to Goldfish Carassius Auratus against Aeromonas Hydrophila. J Vaccines Vaccin 6: 281. doi:10.4172/2157-7560.1000281

Page 6 of 7

mykiss infected with $A$. hydrophila, had increased white blood cells leading to anemia could be attributed to increase destruction, loss, or suppression of RBCs [26].

Thangaviji [20] found that, the serum of $C$. auratus immunized with outer membrane vaccines was agglutinated at the dilutions of 1: 12 level. A. racemosus has been used as a good adjuvant [27] and provides an efficient and sustained immunostimulation to improve the immunogenicity of weak or low dose of antigens. The present study the C. auratus immunized with BOMP had higher titer value than the fish immunized with BOMPG. This may due to more antibody production by the outer membrane protein than the BOMPG. Oral administration of yeast products in channel catfish [28], chitin [29], plant extract including Zingifer officinalis increased the phagocytic capability of the cells in rainbow trout [30] and extracts of four Chinese herbs (Rheum officinale, Andrographis paniculata, Isatis indigotica, Lonicera japonica) were increased the phagocytosis and white blood cells in Crucian carp [31]. The BOMP had also responsible for higher phagocytic activity than the BOMPG in the vaccine treated $C$. auratus. OMP are located at host-bacterial interface and are important for host immune responses and as targets for drug therapy [32]. Fang et al. [3] showed significant protection against two isolates of A.hydrophila in blue gourami, Trichogaster richopterus immunized with a recombinant $43 \mathrm{kDa}$ OMP. Khushiramani et al. [33] isolated 3 to 4 high intensity OMP bands from 40 strains of $A$. hydrophila had the range between 25 to $45 \mathrm{kDa}$. The OMPs extracted from the $A$. hydrophila cell wall and the recombinant OMP gene cloned to the plasmid improved the survival, bacterial load reduction and improved immunological parameters including serum bactericidal activity, lysozyme activity and phagocytosis in the vaccinated $C$. auratus. The OMP may boost the immune system and activate the $\mathrm{T}$ cell as well the $\mathrm{B}$ cell memory. Once the $A$. hydrophila pathogenic interruption happened in the host system, the $\mathrm{T}$ cell as well the $\mathrm{B}$ cell are recognizing the OMP of cell wall of the A. hydrophila and destroy. Even nucleotide vaccines without the recombinant technology also induce the immune system in various fresh water fishes including carp and other ornamental fishes against $A$. hydrophila infection [34]. The present findings revealed the bacterial outer membrane protein (BOMP) had higher immunostimulatory effects against $A$. hydrophila infections than the delivery of BOMPG through vector. The reasons behind it is that outer membrane proteins (BOMP) helps to produce more antibodies than the BOMPG and it may have been easily degraded in vivo conditions. Another possibility is to enhance the immunity by delivering the antigens with adjuvant or microspheres.

\section{Acknowledgment}

The authors gratefully acknowledge the University Grants Commission (UGC), New Delhi, Government of India, for its financial support, in the form Special Assistance Programme (SAP) [UGC NO. F.3-24/2012 (SAP-II) dated October 2012].

\section{References}

1. Zuanon JAS, Salaro AL (2011) Freshwater Fish nutrition. World Aquaculture, The annual international conference, Natal, Brazil, pp. 6-10.

2. Nasser AKV, Rajkumar U (2001) Ornamental fish -prospects for culture Souvenir issued on the Occasion of the inauguration of Visakhapatnam R C of CMFRI, pp. 24-26.

3. Fang HM, Ge R, Sin YM (2004) Cloning, characterisation and expression of Aeromonas hydrophila major adhesin. Fish Shellfish Immunol 16 645-658.
4. Citarasu T, Michael Babu M, Raja Jeya Sekar R, Peter Marian M (2002) Developing Artemia enriched herbal diet for producing quality larvae in Penaeus monodon, Fabricius. Asian Fisheries Science 15: 21-32.

5. Rahman MH, Kawai K (2000) Outer membrane proteins of Aeromonas hydrophila induce protective immunity in goldfish. Fish Shellfish Immunol 10: 379-382.

6. Khushiramani R, Girisha SK, Karunasagar I, Karunasagar I (2007) Cloning and expression of an outer membrane protein ompTS of Aeromonas hydrophila and study of immunogenicity in fish. Protein Expr Purif 51: 303-307.

7. Wolff JA, Malone RW, Williams P, Chong W, Acsadi G, et al. (1990) Direct gene transfer into mouse muscle in vivo. Science 247: 1465-1468.

8. Tang DC, DeVit M, Johnston SA (1992) Genetic immunization is a simple method for eliciting an immune response. Nature 356: 152-154.

9. Thanga Viji S, Michael Babu, M Velmurugan S, Kumaran T, Anand SB, et al. (2011) Virulence Factors and Molecular cloning of Outer Membrane Protein (OMP) gene from virulent Aeromonas hyrophila isolated from infected gold fish Carassius auratus. Bangladesh Journal of Microbiology $28: 70-75$

10. Chakraboty T, Montenegro MA, Sanyal SC, Helmuth R, Bulling E, et al. (1984) Cloning of enterotoxin gene from Aeromonas hydrophila provides conclusive evidence of production of a cytotoxic enterotoxins. Infect Immun 46: 435-441.

11. Laemmli UK (1970) Cleavage of structural proteins during the assembly of the head of bacteriophage T4. Nature 227: 680-685.

12. LOWRY OH, ROSEBROUGH NJ, FARR AL, RANDALL RJ (1951) Protein measurement with the Folin phenol reagent. J Biol Chem 193: 265-275.

13. van KAMPEN E, ZIJLSTRA WG (1961) Standardization of hemoglobinometry. II. The hemiglobincyanide method. Clin Chim Acta 6: 538-544.

14. Hendricks LJ (1952) Erythrocytes counts and haemoglobin determinations for the two species of sucker, genus Catostomus from Colorado. Copeia 4: 265-266.

15. Sritunyaluksana K, Sithisarn P, Withayacsumnarnkul B, Flegel TW (1999) Activation of prophenoloxidase, agglutinin and antibacterial activity in haemolymph of the black tiger prawn, Penaeus monodon by immunostimulants. Fish and Shellfish Immunol 9: 21-30.

16. Park KH, Jeong HD (1996) Enhanced resistance against Edwardsiella tarda infection in tilapia (Oreochromis niloticus) by administration of protein-boun polysaccharide. Aquaculture 143: 135-143.

17. Aoki T, Holland BI (1985) the outer membrane proteins of the fish pathogens Aeromonas hydrophila, Aeromonas salmonicida and Edwardsiella tarda. FEMS Microbiology Letters 27: 299-305.

18. Khushiramani R, Girisha SK, Karunasagar I, Karunasagar I (2007) Protective efficacy of recombinant OmpTS protein of Aeromonas hydrophila in Indian major carp. Vaccine 25: 1157-1158.

19. Thangaviji V, Michaelbabu M, Anand SB, Gunasekaran P, Citarasu T (2012) Immunization with the Aeromonas OMP Provides Protection against Aeromonas hydrophila in Goldfish (Carassius auratus). J Microbial Biochem Technol 4: 2.

20. Thangaviji V, Deepa K, Velmurugan S, Donio MBS, Jenifer J A, et al., (2013) Vaccination strategies to protect goldfish Carassius auratus against Aeromonas hydrophila infection, Diseases in Aquatic Organism 104: 45-57.

21. Yin G, Ardo L, Jeney Z, Xu P, Jeney G (2008) Chinese herbs (Lonicera japonica and Ganoderma lucidum) enhance non-specific immune response of tilapia, Oreochromis niloticus, and protection against Aeromonas hydrophila. Diseases in Asian Aquaculture VI, Fish Health Section, Asian Fisheries Society, Manila 500: 269-282.

22. Rairakhwada D, Pal AK, Bhathena ZP, Sahu NP, Jha A, et al. (2007) Dietary microbial levan enhances cellular non-specific immunity and survival of common carp (Cyprinus carpio) juveniles. Fish Shellfish Immunol 22: 477-486. 
Citation: Divya S, Thangaviji V, Velmurugan S, Michaelbabu M, Citarasu T (2015) Comparative Study on Bacterial Outer Membrane Protein (BOMP) and Bacterial Outer Membrane Gene (BOMPG) Vaccination to Goldfish Carassius Auratus against Aeromonas Hydrophila. J Vaccines Vaccin 6: 281. doi:10.4172/2157-7560.1000281

Page 7 of 7

23. Misra CK, Das BK, Mukherjee SC, Phalguni P (2005) Effect of long term administration of dietary Beta-glucan on immunity, growth and survival of Labeo rohita fingerling. Aquaculture 255: 82-94.

24. Hawk PB, Oser BBL, Summerson WH (1954) Practical Physiological Chemistry, The Blakiston Company, Philadelphia.

25. Sahu S1, Das BK, Pradhan J, Mohapatra BC, Mishra BK, et al. (2007) Effect of Mangifera indica kernel as a feed additive on immunity and resistance to Aeromonas hydrophila in Labeo rohita fingerlings. Fish Shellfish Immunol 23: 109-118.

26. Brenden SA, Huizinga HW (1986) Pathophysiology of experimental Aeromonas hydrophila infection in goldfish, Carassius auratus (L.) Journal of Fish Diseases 9:163-167.

27. Samhita C. Translator (1949) Shree Gulabkunverba Ayurved Society, Jamnagar, India.

28. Ainsworth AJ, Mao CP, Boyle CR (1994) Immune responses enhancement in channel catfish, Ictalurus punctatus, using ß-glucan from Schizophyllum commune. Modulators of Fish Immune Responses I: 67-81.
29. Sakai M, Kamiya H, Ishii S, Atsuta S, Koybayashi M (1992) The immunostimulating effects of chitin in rainbow trout, Oncorhunchus mykiss. Dis in Asian Aquacult, pp: 413-417.

30. Dügenci SK, Arda N, Candan A (2003) Some medicinal plants as immunostimulant for fish. J Ethnopharmacol 88: 99-106.

31. Chen CF, Kusuda RA (1996) Preliminary study on the adjuvant activity of henbane in oral vaccination of grass carp (Ctenopharyngodon idellus). J Huazhong Agric Univ 15: 157-161.

32. Ebanks RO, Goguen M, McKinnon S, Pinto DM, Ross NW (2005) Identification of the major outer membrane proteins of Aeromonas salmonicida. Dis Aquat Organ 68: 29-38.

33. Khushiramani R, Girisha SK, Bhowmick PP, Karunasagar I (2008) Prevalence of different outer membrane proteins in isolates of Aeromonas species. World Journal of Microbiology and Biotechnology 24:2263-2268.

34. Thangaviji V (2014) Protection of gold fish Carassius auratus against Aeromonas hydrophila infection using modern vaccination protocols. $\mathrm{PhD}$ Thesis, Mnonmaniam Sundaranar University, India. 